\title{
Warfare, Civil Conflict and the Spatial Impacts on Domestic Investment: Evidence from South America, 1950-2000
}

\author{
Michael Hicks, Ph.D. \\ Bureau of Business Research \\ and \\ Department of Economics \\ Ball State University \\ Muncie, Indiana 47306 \\ mhicks@bsu.edu \\ Major Jeffrey S Smith, PhD. \\ Graduate School of Engineering and Management \\ Air Force Institute of Technology \\ 2950 Hobson Way \\ Wright-Patterson AFB OH 45433 \\ jeffrey.smith@afit.edu
}

JEL Codes: E22, F21

Key Words: Conflict, Investment, Spatial Econometrics

\begin{abstract}
This paper reports the effect of intra and international conflict on domestic investment in South America from 1950-2000. We combine data from the Penn World Table 6.1 and the Militarized Interstate Dispute Dataset from the Correlates of War project in a spatial investment accelerator model. We find that the magnitude of conflicts (total fatal casualties) is associated with diminished domestic investment, in magnitudes that range from 0.1 percent to one third of total investment across South America's experience in civil wars, conflicts and ethnic wars. We find no evidence of spatial spillovers in South America's civil wars. The paucity of international conflicts in the region leads us to conclude there is no more than suggestive evidence of large impacts and spatial spillovers of international conflicts.
\end{abstract}

The views expressed in this paper are those of the authors and do not necessarily reflect the official policy or position of the U.S. Air Force, the Department of Defense, or the U.S. Government. 


\section{INTRODUCTION}

The United States has an extensive history of policy interventions to strengthen regional investment in nations following armed conflict. These range from modest efforts to improve the capital stock (such as the Peace Corps) to the unprecedented reconstruction efforts of the post World War II Marshall Plan. And, the USA is not alone in these efforts, with international, supra-regional and national efforts aimed to provide quick economic recovery of nations affected by armed conflict. Indeed, it is likely that no developing nation has failed to receive some investment inflows, technical assistance and international aid following its participation in armed conflict. This aid is predicated on the axiomatic belief that investment is affected by war. However, a clear understanding of the empirics of recovery of nations following a war is not available. Estimating the rate of recovery is particularly important in those areas in which international aid or direct assistance may be a major policy instrument of choice.

This paper seeks to estimate the post-conflict recovery patterns - focusing on investment - with an eye towards providing policymakers a clearer understanding of the time commitments required in post conflict assistance efforts. We begin by reviewing the literature, offering an empirical model of investment augmented by national and regional conflict data. We provide the results of the estimation, a summary and policy and research recommendations.

\section{Previous Analysis}

The bulk of existing research which empirically links warfare to economic performance examines either foreign direct investment (FDI) or aggregate growth and convergence. We review this studies with an eye towards teasing from them findings that may inform the question of warfare's impact on aggregate investment. 
Li (2006) looks at political violence and foreign direct investment. Using a Heckman selection model, with net FDI inflows as the dependent variable, Li presents some interesting findings. He finds that civil wars do not affect the probability of FDI, but do have a weak effect on the amount of investment. Conversely, interstate war affects the probability but not the amount of FDI. Finally, terrorism has no effect on either the amount or probability of FDI. Li (2006) further refines his analysis to juxtapose anticipated versus unanticipated conflict, and the results change. Unanticipated civil war negatively affects both the probability and the amount. Unanticipated interstate war affects the probability but not the amount. Interestingly, Gupta et al. (2004), while explaining defense spending's effect on long run growth, note the "resource mobilization" effect from defense spending, where enhanced security provided by increased defense spending make private savings and investment, both domestic and foreign, more attractive. So, we would expect nation states that spend aggressively to maintain a strong defense will be an attractive alternative for investors to employ capital, and correspondingly, they should engage in fewer civil wars and interstate conflicts. This, of course, presumes the spending is for defensive, and not offensive, purposes.

Much of the literature focuses not on the effects of armed conflict on total investment but on the armed conflict's effect on trade flows. Bearce and Fisher (2002) cite numerous examples of previous literature that generally find an inverse relationship between war and international trade. There are many reasons why trade-war linkages are germane to our discussion. As Bearce and Fisher (2002) point out, in lesser developed countries, improvements in infrastructure (read as gross investment) that enable the extraction of natural resources while also facilitating trade, may also be used to ease movement of troops. Thus, investments in infrastructure are natural 
military targets, and therefore it should not be a surprise to see that armed conflict negatively affects investment levels, both domestic and foreign direct.

Collier (1999) describes two scenarios, other than the obvious destruction resulting from conflict, where investment levels in war-torn countries would decrease. One possibility is the dissaving that occurs with the inevitable loss of national income. As long as citizens interpret this phenomenon as temporary, they will dissave to smooth consumption, effectively reducing the amount of capital available for investment. The other possibility mentioned by Collier (1999) is portfolio substitution, where private agents fear the risks associated with the deterioration in security, and shift to other equally attractive opportunities that offer a higher level of safety. Arunatilkae, Jayasuriya and Kelegama (2001) appear to support this finding when they describe a situation where increased military spending acts as a signal, such that lesser developed countries increase spending when the potential for conflict is on the rise. Thus, increased military spending may be a precursor to this portfolio substitution effect, from both domestic and foreign investors. Gupta et al. (2004) argue the opposite, however, that spending on defense ultimately provides better security both within and external to a country's borders, thereby signaling to private investors that it is safe to boost savings, while also attracting more foreign investment. We concern ourselves less with the transmission mechanism between defense spending and investment, and more so with the ultimate effects that occur as a result of the changes in investment.

Bloomberg, Hess and Orphanides (2004) examine the macroeconomic consequences of terrorism. Noting a fundamental difference between terrorism and conflict, they find a strong positive relationship between terrorism and internal conflict, as well as terrorism and the ratio of income to growth. Using a panel approach, terrorism exhibits a small negative effect on growth, 
albeit statistically significant; whereas terrorism exhibits a strongly negative impact on the ratio of investment to GDP. Interestingly, investment responds more negatively to terrorism than the other components of GDP. What Bearce and Fisher (2002) and Murdoch and Sandler (2002) both recognize is that geographical location is a primary actor in these events. Internecine warfare may not confine itself to what may be arbitrarily drawn political boundaries, which cross traditional cultural or tribal demarcation lines. Thus, both internal and external conflicts always run the risk of "bubbling over" into neighboring countries. Even if the civil war is currently selfcontained, rational investors may fear the potential that the civil war will spillover into neighboring countries, diverting foreign direct investment from both the nation involved in the civil war and its neighbors (Murdoch and Sandler 2002). To address this, Murdoch and Sandler (2002) attempt to capture spatial spillovers by modeling civil war intensities in neighboring countries. They use the weighted average of several civil war intensity measures, where the weight is equal to the total shared border ${ }^{1}$. They find that civil wars created a significantly negative influence on short run growth in both the country at war and its neighbors.

Notably, Arunatilkae, Jayasuriya and Kelegama (2001) make the argument that to truly measure the effects of lost investment you must sum the discounted net present value of lost capital services across its physical life, or correspondingly, if the lost physical capital can be replaced, then the cost should be equal to the replacement cost of the asset. While we agree that researchers should be concerned with accurately capturing investment costs, we are more concerned with the effects from the destruction of capital on the steady-state growth path. Ultimately, the time it takes for investment to return to a country previously engaged in armed

\footnotetext{
${ }^{1}$ Murdoch and Sandler use three variables to measure civil war intensity: 1. total months in civil war, 2. total number of deaths from civil wars, and 3. a dummy variable which is 1 if deaths exceed 25,000 . Note that they only use one of these variables when estimating the effects for the country engaged in civil war.
} 
conflict, coupled with the potential loss of investment in surrounding neighbor states, has interesting policy implications as conflict becomes increasingly common.

What we have observed in South America over the last fifty years is a "region that has experienced what we may call a violent form of peace.” (Centeno, pg 35, 2002) This violent peace is characterized by little involvement in international conflict, with internal conflict taking center stage for the better part of the last 200 years (Centeno, 2002). Typical South American wars are limited in duration and geography, arise from economic or border disputes, exhibit brief periods of high intensity, and tend to have little effect on the local populace. (Centeno, 2002). One reason Centeno (2002) gives for the limited international conflict is the most obvious geography. Many countries are separated by the harsh terrain associated with the Andes and Amazon regions, as well as sufficiently large regional buffer zones that have prevent large-scale territorial disputes such as those we have observed in the Kashmir region between India and Pakistan. Without the motivation and with limiting geographic factors, South American states did not develop the logistical necessities to prosecute cross-border wars. Additionally, the domestic conflicts that have flourished in almost every case failed to produce a definitive victor, such that civil wars tended to reach a state of acquiescence instead of capitulation (Centeno, 2002). Thus, the conditions are ripe for continuing domestic conflict. Therefore, as we will show later, domestic conflict more significantly affects investment than international conflicts. The body of research is small, but highly instructive and points directly at the importance of considering war and conflict as factors to consider when evaluating economic growth. Before presenting our model of investment and warfare, we highlight the combination of data we employ in our analysis. The synchronization of these important data elements are improvements in this endeavor. 


\section{THE DATA}

An important part of our research is the combination of two international data sets of interest. We employ the Penn World Tables (PWT) (Heston, Summers, Aten, 2002), version 6.1 and combine this with the Militarized Interstate Disputes (MID v 3.02) data set (Ghosn, Palmer, Bremer, 2004). The PWT 6.1 includes investment, output, value added and population data which are among those applicable to this research. The PWT 6.1 includes data on all the mainland South and Central American countries, and most of the Caribbean nations. The reported PWT data are reported in constant dollar values using a Laspeyres index. There are twenty three variables constructed in the data set (or currently undergoing updates). Among those undergoing updates for inclusion in the data are capital stock data, a limitation which directs our choice of investment modeling. Selected summary statistics, for our sample of South American countries from 1950 through 2000 appear in Table 1.

Table 1, Summary Statistics

\begin{tabular}{lcccccc}
\hline & Mean & Median & Maximum & Minimum & Std. Dev. & Skewness \\
\cline { 2 - 7 } Investment Share of GDP & & & & & & \\
per Capita & 16.7 & 14.9 & 52.3 & -3.6 & 8.1 & 1.28 \\
Real GDP per Worker & 4,327 & 3,876 & 11,639 & 1,513 & 2,093 & 1.03 \\
Population & 13,235 & 4,320 & 170,406 & 146 & 26,086 & 3.93 \\
\hline
\end{tabular}

The MID 3.02 data set is compiled on the Correlates of War (COW) project, which hosts perhaps a dozen distinct data sets on conflict history, conflict intensity, state contiguity, geopolitical and industrial capacity data. Some of the preceding data in this project compiled detailed information regarding warfare to the earliest historical periods. The COW project reports primarily data from the early to mid $19^{\text {th }}$ century through the present. The MID data used in this study includes variables on type of war, intensity (advanced Lickert scale 0-21), duration and estimated fatal casualties. Table 2, provides the MID 3.02 data employed in this study. 
Table 2, Conflicts Employed in this Study

\begin{tabular}{|c|c|c|c|c|}
\hline Begin & Duration & States Directly Involved & Brief Description & Deaths \\
\hline 1949 & 13 years & Columbia & Civil War & 250,000 \\
\hline 1952 & $<1$ year & Bolivia & Civil violence & 2,000 \\
\hline 1954 & $<1$ year & Guatemala & Civil violence (coup against Arbenz) & 1,000 \\
\hline 1955 & $<1$ year & Costa Rica & Civil violence & 1,000 \\
\hline 1955 & $<1$ year & Argentina & Civil violence (army rebellion) & 3,000 \\
\hline 1956 & $1-2$ years & Haiti & Civil violence & N/A \\
\hline 1957 & $<1$ year & Honduras, Nicaragua & International violence (border dispute) & 1,000 \\
\hline 1957 & $2-3$ years & Cuba & Civil war (Castro ousts Batista) & 5,000 \\
\hline 1957 & $10-11$ years & Venezuela & Civil violence & N/A \\
\hline 1960 & $3-4$ years & Cuba, USA & International violence & N/A \\
\hline 1964 & $<1$ year & Guatemala & Civil violence & N/A \\
\hline 1965 & $<1$ year & Dominican Republic & Civil violence & 3,000 \\
\hline 1965 & $<1$ year & Peru & Civil violence & $\mathrm{N} / \mathrm{A}$ \\
\hline 1966 & 29-30 years & Guatemala & Repression of indigenous peoples & 150,000 \\
\hline 1969 & $<1$ year & El Salvador, Honduras & "Soccer War" & 5,000 \\
\hline 1970 & $19-20$ years & Honduras & Civil violence (peasant insurgency) & 1,000 \\
\hline 1979 & $3-4$ years & El Salvador & Civil war (FMLN) & 75,000 \\
\hline 1980 & $<1$ year & Brazil & Repression of dissidents (death squads) & 1,000 \\
\hline 1980 & $<1$ year & Jamaica & Civil violence (elections) & 1,000 \\
\hline 1981 & $<1$ year & Ecuador, Peru & International violence & N/A \\
\hline 1981 & $5-6$ years & Honduras, Nicaragua & International violence & N/A \\
\hline 1982 & $<1$ year & Argentina, UK & Falklands-Malvinas War & 1,000 \\
\hline 1982 & $15-16$ years & Peru & Civil violence (Sendero Luminoso) & 30,000 \\
\hline 1987 & $<1$ year & Chile & Civil violence & 3,000 \\
\hline 1989 & $<1$ year & Panama, USA & International violence & 1,000 \\
\hline 1991 & $<1$ year & Haiti & Civil violence (Aristide presidency) & N/A \\
\hline 1995 & $<1$ year & Ecuador, Peru & International violence (border dispute) & 1,000 \\
\hline
\end{tabular}




\section{A MODEL OF INVESTMENT}

Of interest to us is the role warfare plays on total domestic investment. To test this we posit the traditional accelerator model of investment where capital is a proportionate share of output such that:

$$
K_{i, t}=\gamma Y_{i, t} \quad \gamma \in[0,1]
$$

where investment is the change in the stock of capital, $\mathrm{K}$, representing both the lag change in output, Y, and changes to the net value added to production. Thus;

$$
I_{i, t}=K_{i, t}-K_{i, t-n}
$$

which substituting $\gamma \mathrm{Y}$ for $\mathrm{K}$ and changing notation reduces to:

$$
I_{i, t}=\Delta \gamma K_{i, t}
$$

which is the basic accelerator function. For our empirical specification we add a spatial lag following Aten [1996].

$$
I_{i, t}=\Delta \gamma K_{i, t}+W_{i} I_{j, t-n}
$$


Here $\mathbf{W}$ is the row normalized spatial weight matrix (for a first order contiguity matrix) for the value of the dependent variable in contiguous nation $j$, in time $t-n$. The choice of a temporal lag specification of the spatial component is employed for econometric reasons we detail later. We also include a time autocorrelation component to correct for autocorrelation yielding the function:

$$
I_{i, t}=\Delta \gamma K_{i, t}+W_{i} I_{j, t-n}+\delta \phi_{t-n}
$$

We add to the investment accelerator model our estimates of conflict, the matrix $\Phi$ with $m$ conflict designators (type, intensity and duration), which we lag by one year in all cases to align conflict with investment decisions. To this we add the standard white noise error term $e$, include a logarithmic transformation of the dependent variable for ease of interpretation, a time trend and adding a common and cross sectional specific intercepts provide the empirical specification:

$$
\ln \left(I_{i, t}\right)=\alpha+\alpha_{i}+\Delta \gamma K_{i, t}+W_{i} I_{j, t-n}+\beta_{m} \Phi_{i, m, t-n}+\Phi \mathrm{T}+\delta \phi_{t-n}+e_{i, t}
$$

One criticism of this accelerator model is that it subsumes many policy variables (price and shadow price for capital and aggregate price levels). However, as our intent is to account for conflict response of investment this model effectively balances the need to answer this question in a regional setting.

Several econometric issues arise in this choice of specification. Our first concern, which motivated the lagged spatial autoregression variable, is the potential endogeneity of the 
contemporaneous spatial variable and the dependent variable. Use of a time recursive spatial lag model removes the endogeneity concern, but did not materially affect the coefficient estimates. This makes these types of models attractive in instances where appropriate identifying equations are otherwise elusive. Second, we treat potential heteroscedasticity using version of Whites [1980] heteroscedastic consistent variance-covariance matrix derived from Driscoll and Kraay (1998). The series employed in the regressions are also stationary over the time period examined (Dickey-Fuller tests were employed and are available from the authors). The Durbin-Watson panel statistic reported is derived from Bhargava, Franzini, Narendranathan (1982). As is common, we do not report the values of the cross sectional fixed effects coefficients. Finally, we included a time trend, which effected on the recursive spatial lag coefficient, and is therefore not discussed further.

One difficulty in these types of estimations is in the creation of a measurement variable for conflict. The MID data set is extraordinarily helpful in its estimation of casualties; however, we are not sure if these are the best way to characterize the impact of war. Our three choices are to employ a dummy variable, or account for casualties or per capita casualties. We employ a version of the latter two choices in which our war variable is a linearized value of the estimated fatal casualties across each of the years of the conflict. We discuss the three options in the results section.

Finally, we estimate three distinct models with respect to the types of conflict we evaluate. To execute these models we combine data on internal and external conflicts into two variables. Thus, civil war, internal conflict and ethnic war or violence appears as a single variable. Similarly, any international conflict, be it war or violence is treated the same. What we permit to vary is the type of war we estimate, and whether or not we control for cross border 
spillovers. Our purpose here is two fold. First, we wish to test the sensitivity of a nation to conflicts in which it is involved initially, to validate the model. And, second, there is at least some argument that South America was an aberration in having very little international conflict during the second half of the twentieth century (see Centeno, 2002). This makes us wary of estimating spillovers of international conflict when they are relatively uncommon. We speak more to this later. The result of these efforts leads us to estimate three models, one with only a nation's own wars, one with domestic civil violence only (in both own and contiguous nations), and a full model of both types of conflicts, both domestically and in contiguous nations.

\section{Estimation Results}

Our estimates appear in Table 3.

Table 3, Conflict and the Accelerator Model (dependent variable is $\ln \left(I_{i, t}\right)$ )

\begin{tabular}{|c|c|c|c|c|}
\hline Variable Description & $\begin{array}{c}\text { Mathematical } \\
\text { Operators }\end{array}$ & $\begin{array}{c}\text { Internal Violence } \\
\text { Only }\end{array}$ & $\begin{array}{l}\text { Own Country } \\
\text { Conflict Only }\end{array}$ & Full Model \\
\hline Intercept & $\alpha$ & $\begin{array}{l}16.71680^{* * *} \\
(122.71)\end{array}$ & $\begin{array}{l}16.72235^{* * * *} \\
(121.01)\end{array}$ & $\begin{array}{l}16.71863 * * * \\
(122.04)\end{array}$ \\
\hline Investment Accelerator & $\Delta \gamma K_{i, t}$ & $\begin{array}{l}2.18 \mathrm{E}-10^{* * * *} \\
(4.05)\end{array}$ & $\begin{array}{l}2.11 \mathrm{E}-10^{* * * *} \\
\quad(4.03)\end{array}$ & $\begin{array}{l}2.17 \mathrm{E}-10^{* * * *} \\
(4.03)\end{array}$ \\
\hline $\begin{array}{l}\text { Internal Violence/Conflict (fatal } \\
\text { casualties) }\end{array}$ & $\beta_{1} \Phi_{i, 1, t-1}$ & $\begin{array}{c}-1.51 \mathrm{E}-05^{*} \\
(-1.86)\end{array}$ & $\begin{array}{c}-1.51 \mathrm{E}-05^{*} \\
(-1.85)\end{array}$ & $\begin{array}{l}-1.51 \mathrm{E}-05^{*} \\
(-1.87)\end{array}$ \\
\hline $\begin{array}{l}\text { Internal Violence/Conflict in } \\
\text { Border Country (fatal casualties) }\end{array}$ & $\beta_{2} \Phi_{j, 1, t-1}$ & $\begin{array}{l}5.11 \mathrm{E}-06 \\
(0.22)\end{array}$ & $* * *$ & $\begin{array}{l}9.41 \mathrm{E}-06 \\
(0.28)\end{array}$ \\
\hline $\begin{array}{l}\text { International Violence/conflict } \\
\text { (fatal casualties) }\end{array}$ & $\beta_{3} \Phi_{i, 2, t-1}$ & $* * *$ & $\begin{array}{l}-5.08 \mathrm{E}-05^{* *} \\
(-2.18)\end{array}$ & $\begin{array}{l}1.23 \mathrm{E}-05 \\
(0.94)\end{array}$ \\
\hline $\begin{array}{l}\text { International Violence/conflict in } \\
\text { Border Country (fatal casualties) }\end{array}$ & $\beta_{4} \Phi_{j, 2, t-1}$ & $* * *$ & $* * *$ & $\begin{array}{l}-5.68 \mathrm{E}-05^{* *} \\
(-2.49)\end{array}$ \\
\hline Time Recursive Spatial lag & $W I_{j, t-1}$ & $\begin{array}{l}1.49 \mathrm{E}-11 \\
(0.64)\end{array}$ & $\begin{array}{c}1.36 \mathrm{E}-11^{* *} \\
(4.93)\end{array}$ & $\begin{array}{l}1.39 \mathrm{E}-11 \\
(0.63)\end{array}$ \\
\hline Linear trend & $\Phi \mathrm{T}$ & $\begin{array}{c}0.071^{* * *} \\
(15.87)\end{array}$ & $\begin{array}{l}0.072411 * * * \\
\quad(15.74)\end{array}$ & $\begin{array}{l}0.072492 * * * \\
\quad(15.8)\end{array}$ \\
\hline Time autoregression & $\delta \phi_{t-1}$ & $\begin{array}{c}0.867 * * * \\
(37.07)\end{array}$ & $\begin{array}{c}0.867301 * * * \\
(37.01)\end{array}$ & $\begin{array}{l}0.867156^{* * *} \\
\quad(37.16)\end{array}$ \\
\hline Adjusted R2 & & 0.98 & 0.98 & 0.98 \\
\hline Durbin-Watson (Panel) & & 1.89 & 1.89 & 1.89 \\
\hline $\mathrm{N}$ & & 860 & 860 & 860 \\
\hline Fixed Effects & $\alpha_{i}$ & Yes & Yes & Yes \\
\hline
\end{tabular}


In beginning the evaluation of this estimate, it is clear that the accelerator model itself provides a strong analytical base, and the variables of little interest to our question (time autoregression, linear time trend, and intercept) are stable across these specifications.

Treating the conflict variables in order, we note the strong statistical significance of the internal violence fatalities on investment. The magnitude is, however small. Our estimates here find that 1,000 fatal casualties lead to a little over a 0.0001 percent decline in investment the following year. Notably, the mean value of annual fatal casualties from all types of conflicts in a South American country from 1950 through 2000 was 455 persons. Thus, the cumulative reduction in domestic investment expressed as an average over our sample period is roughly 2.5 percent. The maximum fatal casualties from all multi-year conflicts during the period were just over 19,000 in a year (the linearized value of total war casualties). If we apply this to the longest conflict, (Guatemala's 30 years repression of indigenous persons) would have led to an annual reduction in investment of 1.1 percent per year. Similarly, a one year period of civil violence in Chile, which led to 30,000 fatal casualties, results in an estimated 3.2 percent reduction in investment. These estimates are very much consistent with the estimates of Murdoch and Sandler (2001) who find reductions in total GDP that range from about 0.4 percent for an additional month of conflict, to GDP reductions of as much as 41 percent from major conflict. Compare this to the case of Guatemala which, if all the casualties of their civil conflict occurred over a compressed period, could experience a 16 percent reduction in investment over that period - a magnitude well in line with a large decline in GDP.

We find that in no instance does civil conflict in a neighboring nation reduce investment in a nation. This is different from the findings of Murdoch and Sandler (2001), who found significantly negative, but transient effects using world-wide civil war data. We believe this is 
likely due to our finding of less regional interaction in general in our more geographically limited sample.

In our estimates of own country conflicts only, we find that international conflicts/violence and wars lead to reductions in investment, that are roughly twice as large as the impact of civil violence. However, only in the 1969 'Soccer War' between El Salvador and Honduras did international violence lead to more than a 1,000 casualties, and then a relatively low 5,000 fatal casualties (when compared to the many severe bouts of civil violence). However, in the full model, the impact of international conflict on a nation's investment loses statistical significance. In contrast, the coefficient on international conflict on a nation's border becomes quite large in the full model. At first blush, it appears unlikely that the effect on a nation's investment of a war on one's border in which they do not participate would be larger than an international war in which they actually fight. However, we believe this to be the byproduct of larger forces influencing investment and conflict in the region. Our evidence for this is both empirical and descriptive.

The empirical evidence of this phenomenon is that the time recursive spatial lag variable is only significant in the specification in which we omit all measures of contiguous conflict impacts. And, while this could be the result of relatively few numbers of international conflicts, it is also true that the exposure to international wars is relatively greater when we use the spillover measurement. For example, the 30 year average of 455 'own country' fatal casualties is two thirds less than the 660 annual average casualties experienced by the average border nation. This means that conflicts are fairly heavily concentrated in countries with significant contiguity. So, the exposure to international war on one's border, when you do not participate in the actual conflict is actually greater than one's own exposure to international conflict. This is 
not surprising, but it does mean that the paucity of international wars in South America relative to internal conflicts may lead to spillover effects that swamp domestic disruption. Further, when we more closely examine the nature of the most recent international disputes, two of the three to occur in the last half of our sample period were with out-of-continent neighbors (The Falklands War and the Panamanian Invasion). In both instances, while casualties were large, the impact on domestic investment due to regime change is likely to have been opposite of the expected negative sign.

In the end we believe that inclusion of international wars and conflicts in this estimation are helpful primarily for completeness. We concur with Centeno (2002), that the dominant conflict type in South America has been civil, not international conflict. Thus the large scale lessons to be derived from estimates of international conflict on investment are quite weak in South America.

\section{Conclusion}

We offer a unique combination of two important data sets to provide a basis for analyzing the impact of multiple conflict types on investment. We find that, for a sample of South and Central American countries from 1950-2000 that civil conflict (including, war, civil violence and ethnic conflict) reduces real investment. This impact is large, and in our model of the investment accelerator, which incorporates national fixed effects and a time recursive spatial lag, we find that the largest (in terms of fatal casualties) of South America's civil conflicts reduced investment by perhaps a total of one third over the duration of the conflict. We found very tentative evidence of spillovers, and only in international conflicts, not civil wars. 
These findings are generally in line with the most contemporary estimates of war's impacts (notably Murdoch and Sandler, 2001), and that the differences are largely explainable through differences in dependent variables and geography. However, we believe that additional work testing these results on other geographic regions and with more specific measures of the characteristics of the wars (including timing of fatal casualties and operational characteristics of the forces engaged) will yield more evidence of the magnitude and duration of the impact of war on a nation's economic performance. 


\section{References}

Addison, Toney, Alemayehu Geda, Philipe Le Billon and S. Mansoob Murshed (2005)

"Reconstructing and Reforming the Financial System in Conflict and 'Post-Conflict' Economies" The Journal of Development Studies, vol 41(4) pp 703-718.

Bearce, David H. and Eroc O’N. Fisher (2002) “Economic Geography, Trade and War” Journal of Conflict Resolution, vol 46 (3) pp 365-393.

Bhargava, A., Franzini, L. Narendranathan, W. (1982) "Serial Correlation and the Fixed Effects Models" Review of Economic Studies, Vol. 49(4) page 533-549.

Centeno, Miquel A. (2002) Blood and Debt: War and the Nation-State in Latin America. University Park, PA. The Pennsylvania State University Press.

Collier, Paul (1999) "On the economic consequences of civil war" Oxford Economic Papers 51 pp 168-183.

Driscoll, J and A. Kraay (1998) "Consistent Covariance Matrix Estimation with Spatially Dependent Panel Data” Review of Economics and Statistics Vol. 80, No. 4, Pages 549560.

Fielding, David (2001) "Investment, Employment and Political Conflict in Northern Ireland" Discussion Paper, University of Leicester, \#01/7.

Glick Reuven and Alan M. Taylor (2005) “Collateral Damage: Trade Distruption and the Economic Impact of War” NBER Working Paper \#11565 pp 1-52.

Ghosn, Faten, Glenn Palmer, and Stuart Bremer. 2004. "The MID3 Data Set, 1993-2001: Procedures, Coding Rules, and Description." Conflict Management and Peace Science 21:133-154.

Gupta, Sanjeev, Benedict Clements, Rina Bhattacharya and Shamit Chakravarti (2004) "Fiscal consequences of armed conflict and terrorism in low- and middle-income countries" European Journal of Political Economy vol. 20 pp 403-421.

Heston, Alan, Robert Summers and Bettina Aten, Penn World Table Version 6.1, Center for International Comparisons at the University of Pennsylvania (CICUP), October 2002.

Humphreys, Macartan (2003) "Economics and Violent Conflict" Humanitarian and Conflict Researsh, Harvard University, pp 1-28. 
Imai, Kosuke and Jeremy M. Weinstein (2000) "Measuring the Economic Impact of Civil War" Working Paper, Center for International Development, Harvard, pp 1-27

Murdoch, James C. Todd Sandler (2002) "Economic Growth, Civil Wars, and Spatial Spillovers" Journal of Conflict Resolution 46(1) pp 91 - 110. 